\title{
A-B-O and Rh Affinities between Highland and Lowland Quechua-speaking Peruvian Populations
}

\author{
A. ROBERTO FRISANCHO AND JANE E. KLAYMAN \\ Center for Human Growth and Development and Department of \\ Anthropology, The University of Michigan, \\ Ann Arbor, Michigan 48104
}

KEY WORDS Genetics B Blood groups - Quechua indians Peru.

\begin{abstract}
According to the accounts of the Spanish chronicles and various historical analyses the Quechua-speaking population inhabiting the Province of Lamas in the Eastern Tropical Lowlands of Peru are descendants of the Chanca Tribes that migrated from the highlands about 500 years ago. The results of the present study indicate that in terms of the A-B-O and Rh systems the lowland Quechua-speaking population from the Province of Lamas and the highland Quechua population from the Province of Junin are more similar to each other than to other tropical tribes. Therefore, it is quite possible that the present lowland Quechua-speaking population from the Province of Lamas may be descendants of Andean populations.
\end{abstract}

In the lofty eastern lowlands of Peru live the only Quechua-speaking tropical population currently known as Lamistas. This population according to various historical analyses is supposed to be descended from the ancient Chanca Tribes, who migrated from the Andes after they were defeated by the Incas (Markham, '11; Isquierdo, '60; Vasquez, '49; Weis, '59). Prior to the rule of Inca Pachacutec, the Inca Empire of Tawantinsuyo was disorganized and consisted of several competing confederations of tribes, of which the Chancas and the Incas were the most important. The Chanca Tribes occupied the regions corresponding to the present Departments of Huancavelica, Ayacucho, and Apurimac (fig. 1) in the Central and Southern Highlands of Peru (Balboa, '20; Cieza de Leon, '43; Las Casas, '39; Sarmiento de Gamboa, '40; Rostworowski de Diez Canseco, '53). According to these sources, following their defeat by the Inca Pachacutec around 1350 A.D. the Chancas in the Southern highlands attempted to settle in the area of present Lake Junin which corresponds to the District of Ondores in the Department of Junin in the Central Highlands (fig. 1). However the Inca Pacachutec continued his persecution and the Chancas pursued their escape through the highlands in to the tropical regions and settled near the Mayo River in the Province of Lamas, taking the name Lamistas.

In summary, from the various historical sources and deductions it appears that the present lowland Quechua-speaking native population located in the Province of Lamas are descendants of the former Chanca tribes and as such they come from the same biological stock as many of the highland Indians. Due to the fact that there have been no roads conneoting the highlands with the eastern lowlands until today, the lowland populations have not mixed with those from the highlands. Therefore, in an attempt to determine the possible biological similarities and differences that may exist between these populations, we conducted a study concerned with genetic markers, skin color, growth, reproduction, mortality, etc. In the present article we report data on the affinities for the A-B-O, and $R h$ systems between the Quechua-speaking population from the Province of Lamas in the eastern tropical lowlands and Quechua-speaking populations from the Province of Junin in the Central Highlands of Peru.

\section{METHODS AND MATERIALS}

$$
\text { Sample }
$$

The sample included 175 subjects derived from the Quechua-speaking population of the Village of Pamashto in the Prov- 


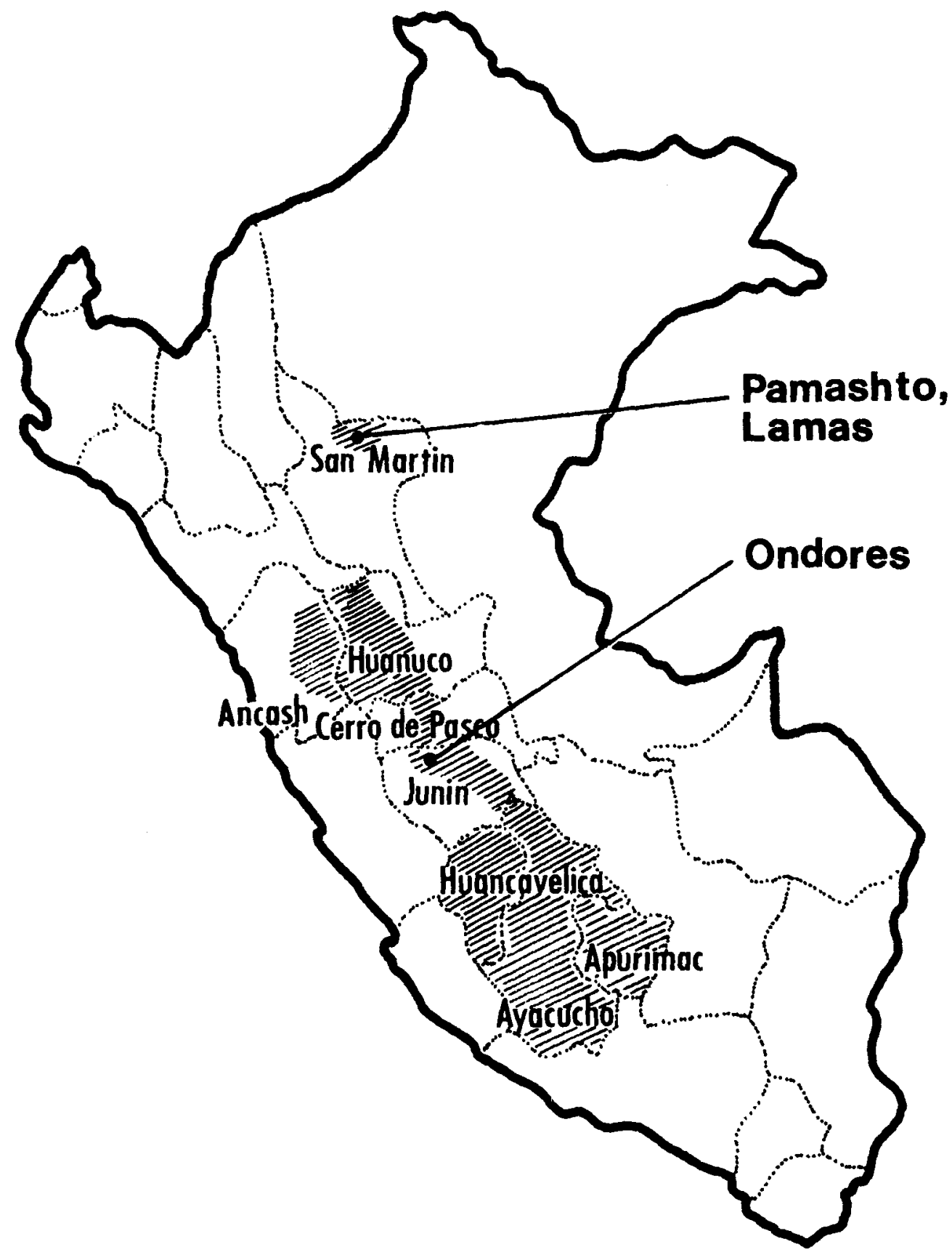

Fig. 1 Map of Peru. The Confederation of Chanca tribes prior to the formation of the Inca Empire occupied the regions corresponding to the present departments of Ayacucho, Apurimac, and Huancavelica. After being defeated by the Inca Pachacutec the Chancas escaped through the Central Highlands through the departments of Junin, Cerro de Pasco, Huanuco and Ancash, into the lowland Province of Lamas in the Department of San Martin. The cross-hatched areas represent the original and subsequent regions occupied by the Chancas. The dotted lines mark the present departments of Peru. 
ince of Lamas of the Department of San Martin in the eastern Peruvian lowlands. At the time of the present study, a total of 118 families resided in the Village of $\mathrm{Pa}$ mashto. (No census data exists for this population). The highland sample included 174 subjects derived from the Quechuaspeaking population of the town of Ondores in the Province and Department of Junin of the Central Peruvian Highlands. According to the Peruvian census, 1961, the District of Ondores had a population of 2,683 inhabitants; 856 were located in the town of Ondores, and 1,827 were in the rural areas.

By finger tip puncture venous blood specimens were derived from the children, ages 6 to 18 years, attending the primary schools of Pamashto in the lowlands and the school of Ondores in the highlands. Antigenic specimens were determined for the A-B-O system and Rh system by the slide agglutination test by the authors and assistants who were trained in blood typing. For the A-B-O system anti-A and anti-B antisera were used, and for the Rh system the blood samples were tested with four specific antisera for the blood factors $\mathrm{C}\left(\mathrm{rh}^{1}\right)$, $\mathrm{D}\left(\mathrm{R} \mathbf{h}^{\mathrm{O}}\right), \mathrm{E}\left(\mathrm{rh}^{\prime \prime}\right), \mathrm{c}\left(\mathrm{rh}^{\prime}\right)$. The reliability of the tests was checked by testing the blood samples with albumin. The gene frequency for the A-B-O and Rh systems were calcuated by a computer program.

\section{RESULTS AND DISCUSSION}

In table 1 are given the phenotypic and genotypic distributions for the A-B-O and $\mathrm{Rh}$ systems in the lowland and highland Quechua-speaking samples. From these data it is evident that the phenotypic and gene frequency for $\mathrm{O}, \mathrm{A}$, and $\mathrm{B}$ are quite similar in both highland and lowland populations. The phenotypic and gene frequency for the $R h$ system in the highlands are also quite similar to those of the lowlands.

In table 2 the gene frequency of the blood groups for the A-B-O and Rh systems of the lowland and highland Quechua populations that we studied are compared to data on highland Quechua populations and tropical tribes studied by other investigators. The data demonstrate that the highland and lowland Quechua populations have a similar gene frequency for the $\mathrm{A}, \mathrm{B}$ and $\mathrm{O}$ blood type. The tropical tribes differ from the highland and lowland Quechua populations by the complete absence of the blood group A or B (only one case with blood B was found among the Shipibo). The frequency for the $\operatorname{CDE}\left(\mathrm{R}^{\mathrm{Z}}\right), \mathrm{CDe}\left(\mathrm{R}^{1}\right), \operatorname{cDE}\left(\mathrm{R}^{2}\right)$

TABLE 1

Distribution of the A-B-O and $R h$ blood groups among lowland (Pamashto, Lamas) and highland (Ondores, Junin) Peruvian Quechua populations

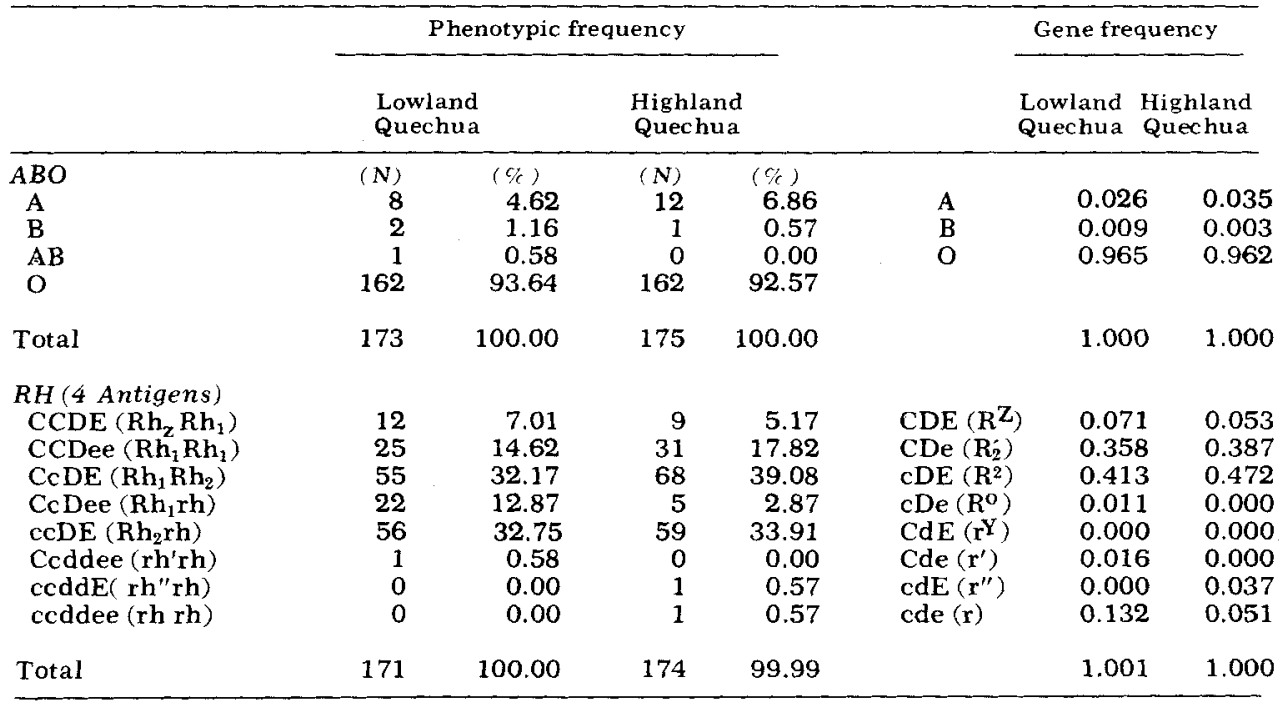




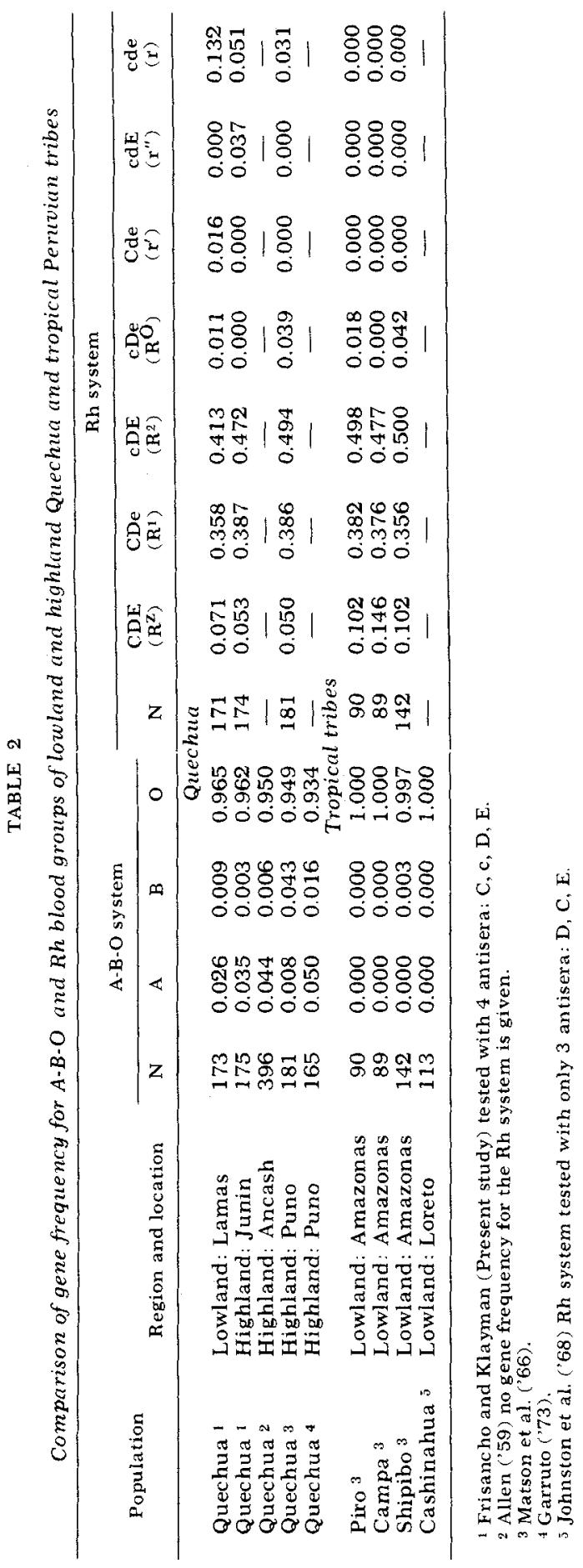

genotypes is very similar in the lowland and highland Quechua populations. The tropical tribes distinguish themselves from the Quechua by the complete absence of the cde(r) genotype.

In conclusion this investigation suggests that the lowland and highland Quechua populations, based on the A-B-O and $\mathrm{Rh}$ blood group systems, have a similar genetic composition. This similarity may be attributed to the fact that genetic variation at the A-B-O and Rh loci, due to either similar selective forces or similar rates of admixture through much of the indigenous populations of South America, is small. However, despite the expected similarity of indigenous populations this study demonstrates that the lowland and highland Quechua populations are more similar to each other than to the other tropical tribes. Therefore, it is quite possible that the present indigenous Quechua-speaking population from the Province of Lamas may be descendants of Andean populations. This similarity suggests then that the differences between the Chancas and Quechuas or Incas were probably of a cultural nature and not of genetic origin.

\section{ACKNOWLEDGMENTS}

We are thankful for the cooperation of the school children, Director and teachers of the schools of Ondores of the Province of Junin and Pamashto of the Province of Lamas, without whom this study would not have been possible. The assistance of Fran Stier and William Lowe, graduates of the Department of Anthropology of The University of Michigan, Jorge Sanchez of the Department of Anthropology of the University of Cuzco, and Obdulio Crispin of the School of Dentistry of the University of San Marcos is acknowledged. The assistance of Dr. Henry Gershowitz of the Department of Human Genetics of The University of Michigan in the blood type training and statistical analyses of gene frequencies is gratefully acknowledged.

The investigation has been supported in part by Grant GS-37542X of the National Science Foundation.

\section{LITERATURE CITED}

Allen, F. H. Jr. 1959 Summary of blood group phenotypes in some aboriginal Americans. Am. J. Phys. Anthrop., 17: 86. 
Balboa, R. P. Miguel Cabello de 1920 Historia del Peru bajo la dominacion de Incas. Col. de iibros y documentos referentes a la historia del Peru. Tomo II, 2 a serie. Lima, Peru.

Casas, F. B. de Las 1939 Las Antiguas Gentes del Peru. Col. de líb. y doc. referentes a la hist. del Peru. Lima, Peru.

Cieza de Leon, P. 1943 Del Senorio de los Incas. Ediciones argentinas "Solar." Buenos Aires.

Frisancho, A. R. 1974 Esudios de diferenciacion y adaptacion entre las poblaciones Quechuas de la selva (Pamashto, Lamas) y Sierra Central (Ondores, Junin) del Peru. Informo, publicado por The University of Michigan, Center for Human Growth and Development, Ann Arbor, Michigan.

Garcilaso de la Vega, I, 1960 Comentarios Reales de los Incas. Ediciones de la Universidad del Cuzco, Peru.

Garruto, R. M. 1973 Polycthemia as an adaptive response to chronic hypoxic stress. Ph.D. Thesis, Department of Anthropology, The Pennsylvania State University.
Isquierdo, G. 1960 El Indio de Lamas. Imprental "La Oriental." Tarapoto, Peru.

Johnston, F. E., R. L. Jantz, K. M. Kensinger, G. F. Walker, F. Allen and M. E. Waler 1968 Red cell blood groups of the Peruvian Cashinahua. Hum. Biol., 40: 508-516.

Markham, C. R. 1911 The Incas of Peru. Smith and Elder, London.

Matson, G. A., H. E. Sutton, J. Swanson, A. R Robinson and A. Santiana 1966 Distribution of hereditary blood groups among Indians in South America. II. In Peru. Am. J. Phys. Anthrop., 24: 325-350.

Rostworowski, M. de Diez Canseco 1953 Pachacutec Inca Yupanqui. Imprenta Torres Aquirre, S. A. Lima, Peru.

Sarmiento de Gamboa, P. 1940 Historia de los Incas. Emecé eds., S. A. Buenos Aires.

Vasquez, M. C. 1949 El primitivo poblador del Huallaga y causas de su extencion. Tesis de et nologia, Universidad de San Marcos, Peru.

Weis, P. 1959 Los Lamas son un pueblo mister ioso. Peru Indigene, 13-16. 